\title{
Taking a MOOC: Socio-Cultural Aspects of Virtual Interaction in a Multicultural Learning Community
}

\author{
Galina Pavlovskaya \\ National Research University Higher School of Economics
}

\begin{abstract}
Correspondence concerning this article should be addressed to Galina Pavlovskaya, English Language Department for Economic and Mathematical Disciplines, National Research University Higher School of Economics, 26 Shabolovka St., Moscow, Russian Federation, 119049.E-mail: gpavlovskaya@hse.ru
\end{abstract}

\author{
Molly Perkins \\ Harvard University
}

\begin{abstract}
Correspondence concerning this article should be addressed to Molly Perkins, Harvard University Massachusetts Hall Cambridge, MA 02138 E-mail: mperkins@gmail.com
\end{abstract}

\begin{abstract}
Featuring different approaches to Massive Open Online Courses (MOOCs) among education policy makers, theorists and practitioners in the field and highlighting an increasing popularity of this educational phenomenon worldwide, the article provides a brief record of MOOCs' success at Harvard University and the National Research University Higher School of Economics (HSE) making the authors move gradually towards the main focus of this paper - socio-cultural problems, that Russian students frequently face while taking a MOOC in English. The survey described in the article revealed that HSE students establishing online communication with their peers from other countries often complain about sudden, unexpected communication breakdowns that they find difficult to explain and that are likely to occur due to the sociocultural differences existing between communication partners in a multicultural learning community. The results of the survey presented in the article indicate that there is an urgent need to find effective ways to increase the students' level of socio-cultural competence that would allow them to communicate successfully in a new virtual learning environment.
\end{abstract}

Keywords: intercultural communication, socio-cultural competence, socio-cultural awareness, MOOCs, virtual interaction, multicultural learning community

Having analyzed a number of publications devoted to MOOCs by Russian and foreign experts, one will inevitably come to the conclusion that there are at least three schools of thought: the first one proclaims the invention of a MOOC a "revolution" (Davidson, Goldberg, 2010; Demillo, Young, 2015), their opponents call MOOCs a "disruptive innovation" (Christensen, Horn, 2013) struggling to find as many darks sides of MOOCs as they can only think of (Kelly, 2014; Mangan, 2013). The most moderate and forwardlooking side of this argument chooses to estimate the economic profitability of a MOOC, to outline its place in the educational market, to predict future perspectives (Kuzminov, Carnoy, 2015) and to find sufficient evidence that can show whether MOOCs are effective in producing desirable educational outcomes (Hollands, Tirthali, 2014).

The increasing popularity of MOOCs is hard to underestimate. In 2013 Harvard and MIT launched their online learning platform edX, offering 68 courses. As reported more people signed up for MOOCs at Harvard in a single year than have attended the university in its entire 377-year history (Rosengbergh, 2015). According to Prof. Robert Lue from Harvard University, institutions that sit back and watch may find themselves in trouble (Dotsenko, 2014). 
The National Research University Higher School of Economics, one of the leading universities in Russia, decided not to sit back but to keep up with the times and to offer its students in Russia and worldwide more than 21 courses on Coursera (Kulik, 2015).

The success of MOOCs is defined by the wide range of opportunities they give their diverse and heterogeneous audience (Gruzdev, Makarov, Semenova, \& Terentev, 2015). The rector of HSE, Prof. Yaroslav Kuzminov outlines at least three target groups that can benefit from MOOCs. The first group is made up of students for whom taking a course means experiencing a new learning environment in the most prestigious and well-established universities of their choice, which now seems to be unlimited and no longer restricted by only one brick-and-mortar university. The second, and frequently the biggest group, are so-called life-long learners and working professionals who can gain new skills and knowledge without making dramatic changes in their schedules. Last but not least are universities themselves and their teaching communities, for whom producing a MOOC is a chance to teach their few but eager students some field-specific courses that are often unprofitable and, consequently, are bound to be excluded from the curricula (Kuzminov, Carnoy, 2015).

However, the success of a MOOC is sometimes considered its biggest disadvantage. Many controversial issues, such as appropriate feedback and adequate assessment of thousands of students enrolled in a course, still remain widely discussed (Sharples, Adams, \& Ferguson, 2014; Kuzminov, Carnoy, 2015).

Meanwhile, students from all over the world seem to ignore this debate and enroll in courses that promise to suit their needs, interests and tastes. For this purpose, students use various online platforms, among which the most popular are Coursera, edx, Udacity, FutureLearn and Open2Study. For them a MOOC is not only a chance to gain new knowledge, skills, and maybe to obtain a verified certificate or a free certificate of attendance but, more importantly, it is an event which allows them to form a new type of a learning community - a global community that unites people with different professional and educational backgrounds.

Unsurprisingly, while students enjoy the benefits of MOOCs, they almost inevitably experience their downsides as well. The survey described further in this article revealed that Russian students who establish online communication with their peers often complain about sudden, unexpected communication breakdowns that they cannot explain. A more detailed investigation in each case has shown that the problems occur due to the socio-cultural differences that exist between communication partners in a multicultural learning community.

\section{Materials and Methods}

As Prof. Victoria Safonova highlights in her article devoted to the most controversial and urgent issues of communicative education in the context of the dialogue of cultures and civilizations, today we are witnessing that the process of forming a global culture that involves online communication is frequently accompanied with a low level of socio-cultural awareness of culturallyspecific features and of what is considered to be polite and impolite in different cultures (Safonova, 2014). This sort of awareness is often considered an integral part of socio-cultural competence - a complex phenomenon including a number of essential and interconnected components. According to G. Zarate and G. Neuner, socio-cultural competence includes an ability to relate to the representatives of other cultures, knowledge of their way of life, a capacity to enter and discover new situations of intercultural exchange, as well as awareness of self and of how people from different cultures see us (Zarate, Neuner, 1997). The lack of socio-cultural competence and socio-cultural awareness may result in communication failures in intercultural communication full of challenges and numerous socio-cultural pitfalls awaiting a FL (foreign language) learner.

In an effort to determine what socio-cultural pitfalls Russian students typically fail to avoid, 450 presentations delivered by Russian EFL learners - the students of different faculties from Voronezh State University were analyzed. The analysis showed that the students made so called socio-cultural mistakes those caused by Russian EFL learners' unawareness of the differences between Russian and foreign traditions, norms, and behavioral patterns (Safonova, Kuzmina, 1998; Pavlovskaya, Kuzmina, 2010). These mistakes may be divided into three major categories that are briefly described in this article ${ }^{1}$.

The first category is classified as verbal sociocultural mistakes that arise in the use of mainly lexical and grammatical means. The most common lexical socio-cultural mistakes are linked to the use of a) pseudo international lexis or "faux amis" and; b) contextually inappropriate lexical units, e.g., the use of pronoun "we", which many Russian EFL learners favor so much when they present the results of their individual scientific research (Wierzbicka, 1992). Grammatical socio-cultural mistakes are connected with the choice of grammatical means that sometimes may appear to be absolutely awkward or even rude. One of the most vivid examples of grammatical socio-cultural mistakes is the use of imperative constructions and modal verbs of obligation that students frequently use to express requests and recommendations (Elizarova, 2005).

The second category includes non-verbal sociocultural mistakes that can be explained by an attitude 
to smiling, using gestures, and establishing an eyecontact, which can vary greatly in different cultures. What is usually regarded as a "natural smile" and "a proper eye-contact" in one culture may be considered bizarre or even irritating in the others (Elizarova, 2005; Leontovich, 2002).

Finally, the third category of socio-cultural mistakes includes verbal, sub-verbal and non-verbal signals that Russian students send to their target recipients basing on the behavioral speech patterns that exist in Russian culture. These mistakes influence the whole manner of delivering information and reacting to the communication partners' needs. As a result, Russian students may seem unwilling to engage into direct and open interaction or may even create the mistaken impression of 'rude and unconcerned' communicators (Elizarova, 2005, p. 344).

Drawing on the works devoted to the problems of intercultural communication of foreign and Russian authors and taking into consideration the results of the analysis briefly described above, we hypothesized that Russian students taking a MOOC in English might encounter similar socio-cultural problems trying to engage in online communication with their peers and tutors. In order to check this assumption the survey described further was conducted.

\section{Research Methods and Procedures}

The survey was conducted amongst first- and second-year students of HSE studying for a Bachelor's degree in "Software engineering". More than 70 students answered the questionnaire, which was mainly focused on the socio-cultural problems the students encounter interacting with their online peers and tutors. The survey included two stages: at the first stage the students were asked to answer a number of questions and the second stage included critical incident analysis that was required to explain the reasons for communication breakdowns reported by the students participating in the survey.

\section{Stage 1: Answering the Questionnaire}

The questionnaire included a number of questions aimed at finding out the following: 1) whether the students have ever taken a MOOC; 2) whether they chose to take a MOOC in Russian or in English; 3) what difficulties they faced communicating with their peers and tutors in a new virtual learning environment.

\footnotetext{
For more examples of typical socio-cultural mistakes in oral pres entations of Rus sian students also see Pavlovskaya, G., Kuzmina, L. (2010). Avoiding Socio-cultural Pitfall While Presenting in English. Moscow: Research center "Euroschool”.
}

Figure 1 shows that $32 \%$ of students have never taken a MOOC either in Russian or in English. The majority of them are first-year students, and while they have not participated in a MOOC yet, they are familiar with the term and hope to take a MOOC in the future. Those who do have experience in online learning prefer taking a MOOC in English; 44\% of students chose field-specific courses in English. Students point out two reasons for this: the course is only available in English, and they consider a MOOC in English to be an effective way to practice their language skills.

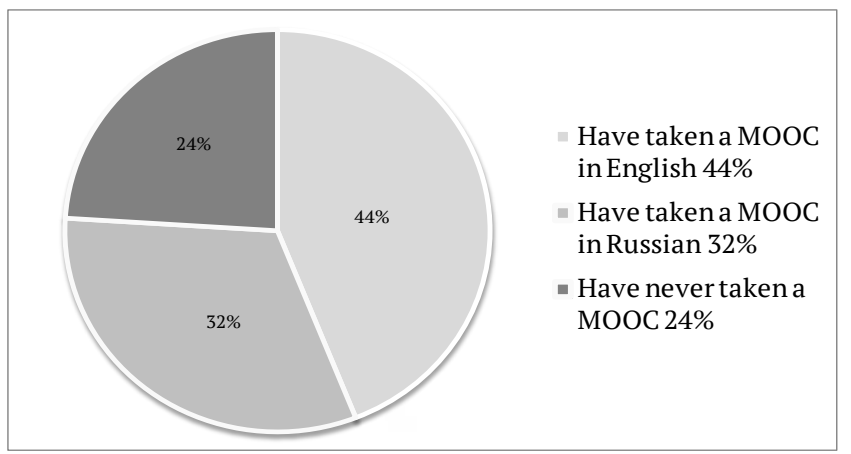

Figure 1. The percentage of students taking MOOCs.

As Figure 2 indicates $57 \%$ of students experience difficulties taking a MOOC in English; disturbingly enough, 38\% of all the students taking part in the survey complain about sudden communication breakdowns. The students from these two categories can be divided into two groups.

The first group is represented by students whose language level is below B1 and who reported experiencing so called "language difficulties" when taking a MOOC in English. They usually try to solve the problem using a dictionary and switching on the subtitles to help them communicate and understand the video lectures and the comments posted on the forums. The second group of students can boast a comparatively higher language level from B2 to $\mathrm{C} 1$; they usually enjoy taking a MOOC in English and actively participate in forum discussions and establish personal contacts with their online peers. Many students from this group claim to be surprised with the situations in which they fail to achieve their communication goals, though their language level allows them to share their ideas easily and articulately.

\section{Stage 2: Analyzing Cultural Incidents}

At this stage we took a closer look at each case that was reported by the students as a situation of a sudden communication breakdown. These cases are usually classified as "critical incidents" (Fowler \& Blohm, 2004) or "cultural incidents" - conflicting or uncomfortable situations which arise because of the 


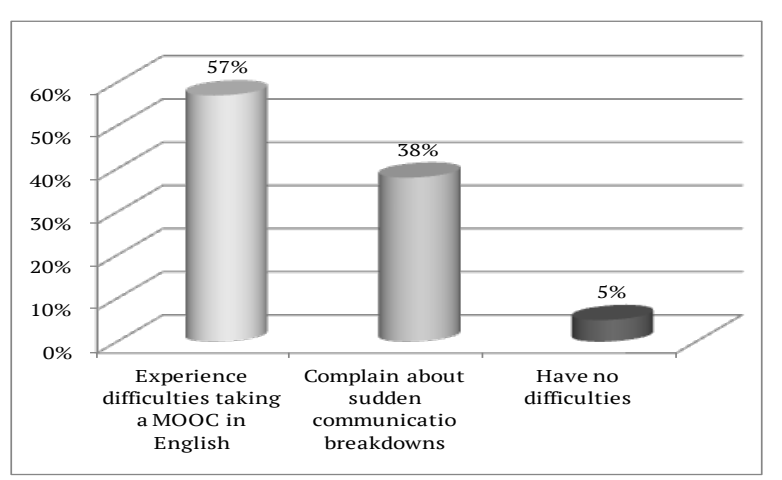

Figure 2. The percentage of students experiencing difficulties while taking a MOOC.

differences in a system of culturally specific values and behavioral norms (Byram, 2001, p. 117). Unawareness of these values and norms may lead to communication failures similar to those described further in this article.

\section{Incident 1: Taboo Topics}

The situation described below was reported by one student who participated in the survey. It can serve an example of one of the numerous pitfalls that students interacting in a multicultural learning community may encounter. After communicating with his online peers for some time, the student was pleased to find like-minded programmers with whom he could discuss the details of a project that he was eager to join. After a while, however, his peers unexpectedly became reluctant to engage even in small talk with him. Further investigation of the incident revealed that the student was trying to receive first-hand information to estimate the profitability of the project, and had asked his online peers about the money and the bonuses that the project brought them personally.

\section{Incident 2: Misinterpreting Visual Information}

One more example is connected with the use of the visual material that the student, participating in the survey, was asked to prepare a presentation to demonstrate the advantages of a new antivirus computer program. The student was proud to come up with a presentation showing a sequence of images for his program that could be used to protect a computer from a "virus". The first slide demonstrated a "virus" in a form of a funny wiggling worm appearing on the computer screen that suddenly turned red and started to beep. The second slide represented a superhero with an antivirus program that turned the suffering computer into a happy and smiling one in the third slide. The final slide included all of the three images appearing in the same sequence. The student reported to have high marks for the presentation but he also mentioned "strange and envious remarks" that he got from some of his online peers who claimed that the presentation was "a complete disaster" on the discussion form.

\section{Results and Discussion}

On the whole, the results of the survey may be summarized as follows. As predicted, the communication failures or cultural incidents described above may be explained by the socio-cultural differences that exist between the communication partners. In the first case, the Russian student lacked awareness of the fact that money is still one of the strictest taboo topics for discussion even in a circle of close friends and relatives in American culture (Ford, 1980; Elizarova, 2005; Leontovich, 2002). On the other hand, asking how much you pay for rent is not considered offensive since housing is an issue of a constant social concern in the USA (Ford, 1980, p. 36). Obviously, this border between money as a matter of "personal concern" and money as a "widely-discussed problem" may not seem very clear for an EFL learner representing a different culture.

The second case deserves special attention since it clearly demonstrates that a learner taking a MOOC enters a virtual learning community that is very culturally diverse. Trying to find out the reasons for the communication failure we referred the student to the peers' personal profiles that helped to realize that they came from Arab countries, and could misinterpret the message being used to reading from right to left. Unsurprisingly enough, the antivirus program presented by the Russian student, seemed to them "a complete disaster" that could damage their computers. The Russian student, in his turn, could not work out the reason for the comments received from his peers and interpreted them as something "strange and envious" because his high marks for the presentation, which he got from the majority of his peers, signaled to him that he had performed quite well. As a result, being unable to account for the socio-cultural differences, both sides were left disappointed and with mutual stereotypes.

As outlined previously, the second stage of our survey was based on critical/cultural incident analysis. This technique has often been described as an effective form of teaching and assessing socio-cultural skills together with other frequently used techniques such as a portfolio, standard cultural tests, diagnostic scales, case studies, interviews, analysis of reflective diaries, and logs (Byram, 2001; Deardoff, 2006, Jackson, 2005). On the other hand, all of them have been questioned for the validity of the received results and criticized for testing only factual knowledge 
which is often generalized and stereotypical (Hashem, 1995). Though the danger of building stereotypes is sometimes very high, we share G. Neuner's views based on the assumption that socio-cultural mistakes in intercultural communication are inevitable and it is essential to help FL learners realize that "such breakdowns in comprehension and communication are quite natural and will occur again and again at all stages of foreign language learning and use" (Neuner, 2003, p. 50). Analysis of the reasons for communication breakdown in intercultural communication gives students "comprehension of the other culture" that is required to "defuse the incident and clear the way for better understanding in the future" (Archer, 1986, p. 172).

\section{Conclusion}

The results of the survey presented in this article demonstrate an urgent need for Russian EFL learners to increase the level of socio-cultural competence that serves as the basis for developing a better understanding of a foreign culture as well as of one's own, and helps to establish successful intercultural communication. Taking into consideration an increasing number of international contacts, a considerable share of which has become possible thanks to modern technology, it is particularly important to find ways to increase the students' level of socio-cultural competence that would allow them to communicate effectively in both real and virtual multicultural learning communities. Though MOOCs are sometimes heavily criticized for a number of reasons, it is quite obvious that in taking a MOOC a learner joins a virtual learning community that can give real experience of intercultural communication, and this opportunity should not be ignored either by the researchers and the teachers or by the learners themselves.

\section{References}

Archer, C. (1986). Culture bump and beyond. In J. M. Valdes (Ed.), Culture bound: Bridging the cultural gap in language teaching (pp. 170-178). Cambridge, UK: Cambridge University Press.

Byram, M. (2005). European language portfolio. Theoretical model and proposed template for an autobiography of 'key intercultural experiences'. Strasbourg, France: Council of Europe Publishing.

Byram, M., Nichols, A., \& Stevens, D. (2001). Developing intercultural competence in practice. Clevedon, UK: Multilingual Matters.
Davidson, C. N., \& Goldberg, D. T. (2010). Future of thinking: Learning institutions in a digital age. Retrieved from https://mitpress.mit.edu/sites/ default/files/titles/free_download/9780262513746_ Future_of_Thinking.pdf

Deardorff, D. (2006). Identification and assessment of intercultural competence as a student outcome of internationalization. Journal of Studies in International Education, 10(3), 241-266.

Demillo, R. A., \& Young, A. J. (2015). Revolution in higher education: How a small band of innovators will make college accessible and affordable. Cambridge, MA: The MIT press.

Dotsenko, S. (2013, October 16). MOOCs: Can they produce the next Einsteins? Retrieved from http:// www.huffingtonpost.com/svetlana-dotsenko/ moocs-can-they-produce-th b 4099322.html

Elizarova, G. (2005). Cultura i obuchenie inostrannym yazykam [Culture and foreign language teaching]. St. Petersburg, Russia: KARO.

Ford, C. (1980). Charlotte Ford's book of modern manners. New York, NY: Simon \& Schuster.

Fowler, S. M., Blohm J. M. (2004). An analysis of methods for intercultural training. In D. Landis, J. Bennet \& M. Bennet (Eds.), Handbook of intercultural training (pp. 37-84). London, UK: Sage.

Gruzdev, I., Makarov, K., Semenova, T., \& Terentev, E. (2015). Who takes HSE courses on Coursera? The differences between economics, humanities and math-intensive courses. Higher Education in Russia and Beyond. Physics and Lyrics: Disciplinary Divide in Post-Soviet Academia, 3(5), 22-24.

Hashem, M. (1995). Assessing student learning outcome in teaching intercultural communication. Speech communication association convention. Retrieved from http://eric.ed.gov/ERICDocs/data/ericdocs2/ content_storage_01/000000b/80/26/04/92.pdf

Hollands, F., Tirthali, D. (2014). MOOCs: Expectations and reality. Full report. Retrieved from http://cbcse. org/wordpress/wp-content/uploads/2014/05/ MOOCs_Expectations_and_Reality.pdf

Horn, M., \& Christensen, C. (2013, February 20). Beyond the Buzz. Where are MOOCS really going? Retrieved from http://www.wired.com/2013/02/beyond-themooc-buzz-where-are-they-going-really/

Jackson, J. (2005). Assessing intercultural learning through introspective accounts. Frontiers: The Interdisciplinary Journal of Study Abroad, 11, 165186.

Kelly, A. (2014). Disruptor, distracter or what? A policymaker's guide to Massive Open Online Courses (MOOCs). Retrieved from http:// bellwethereducation.org/sites/default/files/BW MOOC_Final.pdf

Kramsch, C. (1993). Context and culture in language teaching. New York, NY: Oxford University Press. 
Kulik, E. (2015). Strategii i perspectivy obrazovatelnyh tehnologiy [Strategies and perspectives of educational technologies]. Okna akademicheskogo rosta, 14(109). Retrieved from https://www.hse.ru/ data/2015/10/12/1076112699/okna_109.pdf

Kuzminov, Y., Carnoy, M. (2015). Onlayn-obuchenie: Kak ono menyaet strukturu obrazovaniya i ekonomiku universiteta [Online-learning: How it affects the university structure and economics]. Voprosy Obrazovaniya, 3, 8-43.

Leontovich, O. (2002). Russkie $i$ amerikantsy: Paradoksy mezhkul'turnogo obschenija [Russians and Americans: Paradoxes of intercultural communication]. Volgograd, Russia: Peremena.

Mangan, K. (2012, October). Massive excitement about online courses. MOOC mania. Retrieved from http://chronicle.com/article/Massive-ExcitementAbout $/ 134678$

Neuner, G. (2003). Socio-cultural interim worlds in foreign language teaching and learning. In $\mathrm{M}$. Byram (Ed.), Intercultural competence (pp. 15-62). Strasbourg, France: Council of Europe Publishing.

Pavlovskaya, G., Kuzmina, L. (2010). Sociokul'turnye osobennosti prezentatsii na angliyskom yazyke [Avoiding socio-cultural pitfall while presenting in English]. Moscow, Russia: Research centre "Euroschool".

Rosenbergh, J. S. (2015). Online education: Much more about MOOCs. Harvard Magazine. Retrieved from http://harvardmagazine.com/2015/04/harvardmooc-online-learning-lessons-from-edx

Safonova,V.V. (2014). Communicative education in the context of the dialogue of cultures and civilizations. Procedia, Social and Behavioral Sciences, 154, 57-63.

Safonova, V. V., Kuzmina, L. (1998). Tipologiya sociokul'turnyh oshibok $v$ angloyazychnoj pis'mennoj rechi russkih obuchyaemyh [Typology of sociocultural mistakes in English written speech of Russian students]. Inostrannye Jazyki v Shkole, 5, 31-34.

Sharples, M., Adams, A., Ferguson, R., Gaved, M., McAndrew, P., Rienties, B., Weller, M., \& Whitelock, D. (2014). Innovating pedagogy 2014: Open university innovation report 3. Milton Keynes, UK: The Open University.

Vassilieva, I. (1998). Who am I / who are we in academic writing. International Journal of Applied Linguistics, 8(2), 163-190.

Wierzbicka, A. (1997). Understanding culture through their key words. English, Russian, Polish, German and Japanese. New York, NY: Oxford University Press.

Zarate, G., Neuner, G. (1997). Sociocultural competence in language learning and teaching: Studies towards a common European framework of reference for language learning and teaching. Strasbourg, France: Council of Europe Publishing. 